\title{
Nieuwe tijd
}

Ernst van den Boogaart, Vreemde verwanten. De wereld buiten Europa 1400-1600 (Vantilt; Nijmegen, 2019) 384p., ill., €29,95 ISBN 9789460044618

\section{Strangers, relatively}

Ernst van den Boogaart's latest study focuses on the growth of European knowledge of lands and peoples beyond Europe resulting from voyages over the first half of the early modern period. The work delineates the development of the cosmography genre into geography and ethnography, focusing on persistent themes and methodologies. As the title indicates, an analysis of the knowledge of newly encountered peoples and their place in the human family takes centre stage. Following previous work by the author, the present volume endeavours to take text as well as images as equally important historical sources.

The study relies on a selection from manuscripts and published texts and images produced in the two-hundred-year period surveyed. Chapter one explores T-O maps and the journeys of Marco Polo and John Mandeville, defining European conceptions of the known world around 1400. The book follows a chronological itinerary thereafter, the route defined by stops along the different regions that progressively expanded the limits of European maps and ethnography. Each chapter after the first focuses on a specific place and period, ending with a view of the world and its peoples as it appeared to Abraham Ortelius at the close of the sixteenth century. Chapter two is noteworthy for its analysis of the exploration and reports of West and Southern Africa. Passed over in most surveys of European exploration, the period is shown to be of crucial importance in understanding the creation of the ethnographic toolkit.

Although each region and its peoples are discussed in separate chapters, Van den Boogaart's analysis of the development of the methods of geography and ethnography lends continuity and coherence to the volume. He finds that Europeans tended to ask similar questions in different places and times: what are the natural features, and flora and fauna of a region? What kind of climate and natural resources does it possess? Ethnographical interests across space and time seem to be concentrated around the issues of religion, clothing, domestic lifestyle, eating habits, technology, agriculture, marriage and funerary customs, social and political hierarchy, and war-making. The homogeneity of issues across different settings allowed the identification of indices for a scale of civilization - on which Europeans generally occupied the highest position - through which to classify the peoples of the world. In parallel, this led to the development of comparison as a method, the bread-and-butter of most ethnographers since. Notwithstanding - as the works of André Thevet and Jean de Léry on America show (chapter six) - the tension between observation, beliefs, and a tradition of Classical and Biblical knowledge could produce different analyses even in the same timeframe. 
Each work is embedded deeply in its particular historical contexts - the author's personal and intellectual life, the relevant European state's politics, indigenous-European interactions in the period and place reviewed, publication and circulation history - providing a holistic picture of the circumstances in which knowledge of the foreign was produced and received. The reader is thereby presented with a method to order the mass of early modern knowledge of places and peoples. Vreemde verwanten does not present an incremental account of knowledge creation, but an analysis that identifies the enduring themes of interest and manners of presentation that contributed to the creation of a consistent body of knowledge rather than a jumble of facts. Van den Boogaart departs from most works in this field in his treatment of images as historically significant forms of knowledge and pedagogic devices rather than mere illustrations. The transition from schematic TO maps to the mathematical layout of Ortelius's Theatrum orbis terrarum (chapter nine) explicates changes in representational practices. America's entrance on Waldseemüller's map of 1507 (chapter three), a mere 18 years after Henricus Martellus's (chapter two) world map - showing only Afro-Eurasia - is emblematic of the rapid, dramatic changes that the picture of the world underwent. Maps of Africa appeared in Lopes's Relatione del reame di Congo (chapter eight) together with ethnographic illustrations - signalling an equivalence in the epistemic value of the two.

Every chapter devotes separate space to studying the images that visualised foreign locales and their denizens. Two chapters are dedicated to sources that are almost entirely visual, viz. the Old World pageants of Hans Burgkmair (chapter four) and the enigmatic Codex Casanatense (chapter five). These emphasise the centrality of images in recording knowledge about the overseas world as well as visual schemes that characterised ethnographic illustration. Consistent visual schemes allowed the readers to play ethnographer and evaluate cultural traits via comparison - as the author goes to some pain to demonstrate, images were informative beyond mere physical description. Man-woman pairings for instance educated the viewer not only regarding the physical appearance but also social hierarchy (through clothing or absence thereof, for instance), war making (by the depiction of arms), matrimonial customs (poly- or monogamy), among others - all of which helped the viewer-reader evaluate civilizational development. The Picts and Indians of John White (chapter seven) bear testament to the idea that the newly discovered "primitive" peoples could shed light on the ways of the ancestors of the Europeans themselves. Curiously, given the large number of finely reproduced images in the book, no enumeration is used, leaving the reader to make correlations between the text and the relevant figures.

Vreemde verwanten is a dense and fascinating account of the development of European knowledge of the extra-European world. The work identifies concerns that defined the emerging genres of geography and ethnography, revealing continuities and changes in ideas as well as methodologies employed in the pursuit of knowledge in both word and image. While Classical-Biblical models of the form of the world and of ethnogenesis proved to 
be stubborn, empirical experience as well as economic, political, and cultural exigencies brought new questions to bear upon existing conceptions of 'Others'. The overwhelming success of the volume lies in demonstrating how conventional historical sources regarding the non-European world can be equally informative for understanding Europe and its ways of conceptualising civilization.

Neilabh Sinha, Universiteit Leiden

Enny de Bruijn, De hoeve en het hart. Een boerenfamilie in de Gouden Eeuw (Prometheus; Amsterdam 2019) 368p. €24,99 ISBN 9789044640618

\section{Wellust, geweld en geloof in een dijkdorp}

In de historiografie van de Nederlandse Republiek spelen steden de hoofdrol. Het platteland moet het doen met een bescheiden bijrol, waarbij de aandacht vooral uitgaat naar de sociaaleconomische betekenis van het vroegmoderne boerenbedrijf. Cultuur- en mentaliteitsgeschiedenissen van het zeventiendeeeuwse Noord-Nederlandse landleven zijn schaars, behoudens Van Deursens poldervariant van Montaillou. Die levendige studie naar het Hollandse dorp Graft, verschenen in 1994, was mogelijk dankzij een keurig bewaard archief én de vlotte pen van de auteur. Een kwart eeuw later publiceert neerlandica Enny de Bruijn met De hoeve en het hart een vergelijkbaar boek. Centraal hierin staan enkele generaties van een boerenfamilie in het Gelderse dorp Herwijnen en het buurdorpje Hellouw in de Tielerwaard.

Basisbron voor De Bruijn, die in 2012 promoveerde op een biografie van de dichtende predikant Jacob Revius, is de correspondentie van een naar Leiden verhuisde boerenzoon met zijn in Herwijnen achtergebleven familie. Op zoek naar de geschiedenis en genealogie van zijn voorvaderen bestookte hij hen met vragen over het verleden, wat resulteerde in 180 brieven. Aanvullende informatie en controle van gekleurde feiten en overdreven heldenverhalen haalde De Bruijn onder meer uit de archieven van de rechtbank van Tuil, het Hof van Gelre, de nabijgelegen stad Zaltbommel en vooral de kerkelijke registers van gemeente en classis. Op basis van dit corpus voert zij de lezer langs talloze aspecten van het boerenleven in Herwijnen. Tot de circa achthonderd dorpsbewoners behoorde een grote groep boeren. Ze waren gespecialiseerd in de fruitteelt en paardenhandel, maar verbouwden ook hop, graan, bonen en erwten en hielden ossen, koeien en schapen. In slechte tijden verdienden ze een centje bij met vissen, vogelkooien of met het uitbaten van herbergen. Daar kon het er ruig aan toegaan. Tijdens 'voorbruiloften' en andere feesten ging de Herwijnense jeugd zich te buiten aan drank en voorechtelijke seksuele escapades. Desondanks was het percentage 'zwangerschapshuwelijken' in het dorp aan de lage kant. Dat de boeren zó hechtten aan een erfgenaam dat ze pas trouwden als ze hun toekomstige bruid hadden bezwangerd, een veelgehoorde sociologische stelling, blijkt hier 